\title{
HEMOCULTURES FOR THE PARASITOLOGICAL DIAGNOSIS OF HUMAN CHRONIC CHAGAS' DISEASE
}

\author{
Egler Chiari1, João Carlos Pinto Dias², Marta Lana ${ }^{3}$ and Clea Andrade Chiari 1
}

\begin{abstract}
With the purpose of standardization of an hemoculture technique presenting a higher positive rate in the parasitological diagnosis of chronic Chagas' disease in patients with reactive serology (IFT, HA, CFT) the following schedule was used. Thirty ml of venous blood was collected with heparin and the plasma was separated by centrifugation (2.000 rpm/30'). The packed cells were washed with LIT medium or PBS which was then removed by centrifugation $\left(2.000 \mathrm{rpm} / 15^{\prime}\right)$. This material was sampled in 6 screw-tubes $18 \times 200$ with $6 \mathrm{ml}$ of LIT medium and incubated at $28^{\circ} \mathrm{C}$. These incubated cultures at $28^{\circ} \mathrm{C}$ were examined after $15,30,45$ and $60^{\circ}$ days. When the hemoculture was not immediately processed after blood collection, the plasma was removed and the sediment enriched with LIT medium and preserved at $4^{\circ} \mathrm{C}$. The Xenodiagnosis was performed according to Schenone's method used here as a reference technique.

Among the various groups of patients examined by both techniques the best results obtained were: $55.08 \%$ of positivity for hemocultures against $27.5 \%$ for xenodiagnosis $\left(X^{2}=4.54, p=0.05\right)$, with a tube positivity of $26.6 \%$.

Recommendation for screening trials of drug assays is the repetition of method on a same patient 2 or more times in different occasions, as used in xenodiagnosis.
\end{abstract}

Key-words: Chagas' disease. Parasitological diagnosis. Hemoculture and xenodiagnosis. Trypanosoma cruzi.

For several years the hemocultures were not currently performed for the diagnosis of chronic Chagas' disease because authors such as Pedreira de Freitas ${ }^{7}$ and Pifano ${ }^{16}$ obtained negative results and a low level of positivity $(6.3 \%)$.

Since Chiari \& Brener ${ }^{4}$ obtained $31.8 \%$ of positive blood culture in LIT medium, the opinion about the method changed and new possibilities of research appeared. It was possible, by using mainly liquid media with direct seeding (or after centrifugation of the material in different schedules) to use experimental and human blood culture for diagnostic purposes.

Several attempts have been made to improve the parasitological diagnosis of human Chagas' disease by using hemocultures ${ }^{14}$. Mourão \& Mello ${ }^{12}$ were engaged in the development of their idea to remove the plasma, to wash the cells with the purpose of taking off antibodies or other inhibition factors for the growth

1. Universidade Federal de Minas Gerais.

2. Fundação Oswaldo Cruz, Universidade Federal de Minas Gerais e SUCAM (Divisão de Doença de Chagas).

3. Universidade Federal de Ouro Preto.

Financiado em parte pelo CNPq, FINEP.

Endereço para correspondência: Prof. Egler Chiari. Departamento de Parasitologia/ICB. CP: 2486 - 30161 Belo Horizonte, MG - Brasil.

Recebido para publicação em 14/06/88. of Trypanosoma cruzi. At the end of same year Chiari $\&$ Dias $^{6}$, reproducing the technique of above mentioned authors started a pilot project in which they attempted to change the blood volume from 10 to $30 \mathrm{ml}$ to obtain better positivity earlier and also to try new media like Warren 820 and others. Experimental approaches made by Neal and Neal ${ }^{13}$ \& Miles ${ }^{14} 15$ in further investigations with Warren's medium showed that between 10 and 20 trypomastigotes can reliably give positive cultures. All these above mentioned papers suggest the use of hemocultures associated or not with xenodiagnosis in patients with chronic Chagas' disease. The importance of hemoculture technique for parasitological diagnosis is the assessment of drug activity in clinical trials with human chronic Chagas' disease. The ideal method should be simple and practical, giving a quick growth of flagellates. Furthermore, hemoculture methods are also desirable since xenodiagnosis presents some practical limitations such as allergic reactions to the insect bite, low sensitivity in human chronic disease and several problems to maintain a large insectary.

\section{MATERIAL AND METHODS}

Blood is collected from chronic patients with positive serology to Chagas' disease (IFT, CFT, HA). Volumes of $30 \mathrm{ml}$ of venous blood are collected with heparin to be processed. If it is not possible to process 
Chiari E, Dias JCP, Lana M, Chiari CA. Hemocultures for the parasitological diagnosis of human chronic Chagas' disease. Revista da Sociedade Brasileira de Medicina Tropical 22: 19-23, jan-mar, 1989.

this material immediately blood can be kept in the refrigerator at $4{ }^{\circ} \mathrm{C}$, atter the substitution of the plasma by equal volume of LIT medium. Plasma is removed by centrifugation at $2,000 \mathrm{rpm}$ for 30 minutes. This material should be kept in the refrigerator or ice-bath untill the complete processing of the whole technique.

\section{Hemoculture processing}

After the removal of the plasma, the packed cells must be washed with LIT medium or physiological buffer saline (PBS) that is then removed by centrifugation $(2,000 \mathrm{rpm} / 15$ minutes $)$. This material is sampled in 6 screw-tubes $18 \times 200$ with $6 \mathrm{ml}$ of LIT medium and incubated at $28{ }^{\circ} \mathrm{C}$. Every 2 days the hemocultures tubes must to be agitated in order to homogenize the material.

\section{Hemoculture examination}

Fresh preparations are examined after 15, 30, 45 and 60 days after seeding, between slide and coverglass $22 \times 22$, with $100 x$ and $400 x$ magnifications. The sample volume must be always $0.10 \mathrm{ml}$ to give a good slide preparation, collected on the surface of sedimented cells, and the LIT medium liquid phase. Such process permits to obtain an uniform suspension that facilitates the search of flagellates and amastigotes clumps, almost always without movement. After 60 days (or 75 days) the negative tubes are centrifugated at 2,000 rpm/15 minutes and the sedimented material is examined.
Xenodiagnosis were carried according to Schenone et alii18 19 method with $403^{\text {nd }}$ instar of Triatoma infestans examined after 30 and 60 days.

The chi-square $\left(\mathrm{X}^{2}\right)$ test was used. The significance level of $5 \%$ was accepted for all tests.

\section{RESULTS}

Table 1 shows results of xenodiagnosis done in a group of 40 pacients, from which $30 \mathrm{ml}$ of venous blood was collected for hemoculture. The packed cells obtained from the $30 \mathrm{ml}$ of venous blood were washed in PBS and distributed in 6 tubes containing LIT medium.

Table 2 shows the results of the comparison of the material in which the plasma is immediately removed after collection or when the plasma is not removed.

Table 3 shows the results of xenodiagnosis and hemoculture when blood-plasma is removed and equal volume of LIT medium is additioned.

When the heparinized blood of 20 patients was kept at room temperature for $24-48$ hours, the percentage of positive tubes was reduced to half. The methodology was the same as in the previous experiments.

Table 1 - Positivity of xenodiagnosis (Schenone method) against the hemoculture in LIT medium (Mourâo and Mello technique modified) performed simultaneously in human chronic phase of Chagas' disease (Bambuí, MG).

\begin{tabular}{lcccc}
\hline Method & Positive & Negative & Total & \% of positive \\
\hline Xenodiagnosis & 12 & 28 & 40 & 30.0 \\
Hemoculture & 22 & 18 & 40 & 55.0 \\
\hline Total & 34 & 46 & 80 & \\
\hline Positivity/tube & $11 \%$ & $\mathrm{X}^{2}$ of 5.11 & $\mathrm{p}=0.0238$
\end{tabular}

Table 2 - Positivity of hemoculture tubes which the plasma was or was not removed after to have blood collected and before to process $24-48$ hours in refrigerator or ice-bath in transport to laboratory using same technique.

\begin{tabular}{lcccc}
\hline Plasma & Positive tubes & Negative tubes & Total & \% of positive tubes \\
\hline Without & 14 & 64 & 78 & 18.0 \\
With & 7 & 90 & 97 & 7.2 \\
\hline Total & 21 & 154 & 175 & \\
\hline
\end{tabular}

$$
\mathrm{X}^{2}=5.5175 ; \quad \mathrm{p}=0,018
$$


Chiari E, Dias JCP, Lana M, Chiari CA. Hemocultures for the parasitological diagnosis of human chronic Chagas' disease. Revista da Sociedade Brasileira de Medicina Tropical 22: 19-23, jan-mar, 1989.

Table 3 - Positivity of xenodiagnosis (Schenone) and hemoculture with $30 \mathrm{ml}$ of blood-heparinised collected. Plasma is removed by centrifugation and addition of equal volume of LIT medium in a group of 29 patients of chronic Chagas' disease (Bambuí, MG).

\begin{tabular}{lcccc}
\hline Method & Positive & Negative & Total & \% positives \\
\hline Xenodiagnosis & 8 & 21 & 29 & 27.5 \\
Hemoculture & 16 & 13 & 29 & 55.5 \\
\hline
\end{tabular}

Total

24

34

58

Positivity/tube: $\quad 26.6 \% \quad \mathrm{X}^{2}$ of $4.54 \quad-\mathrm{p} 0,033$

\section{DISCUSSION}

Our hemoculture studies supported the findings of Mourão \& Melo ${ }^{12}$. After the first confirmation of the results by Chiari \& Dias ${ }^{6}$, some technical changes, were introduced. Instead of using $10 \mathrm{ml}$ of blood (as used in their original method), or $20 \mathrm{ml}$ as they previously tested, $30 \mathrm{ml}$ of blood was used in order to increase positivity. Another change was the use of LIT medium to wash the packed cells in place of PBS. In Table 2 the reduction from 18.0 to $7.2 \%$ positivity/ tubes is probably due to the lytic action of immunoglobulins present in the plasma of chronic patients or, according to Pifano ${ }^{16}$, due to macrophage potential of existing lymphocytes in the material. In order to study the inference of "chagasic" plasma on the parasite development we added different amounts of plasma collected from normal and chronic infected individuals in $T$. cruzi cultures. Such experiments show an important inhibition of "chagasic" plasma on the cultures growth in comparision to the normal development of those in which not infected plasma was added (Chiari et ali $^{5}$ ). The addition of LIT medium after the removal of the plasma aims at adapting the present flagellates to a new metabolic pathway in the LIT medium, as accepted by Pifano 16 . Such addition does not increase the positivity of the hemoculture, but increases the number of positive tubes per patient, thus facilitating the detection of flagellates in microscopic examination (26.6\%) against 11.0 to $18.0 \%$ of other technical procedures (Tables 1, 2 and 3).

After many changes, some attempts to standardize the technique are being made. When the hemoculture is not processed immediately, $30 \mathrm{ml}$ of heparinized blood is used, with the removing of the plasma and its substitution for LIT medium. When the method is immediately processed the cells are washed in LIT medium, the medium is then removed by centrifugation and the cells are seed in new LIT medium. In the first instances the material must be kept at $4{ }^{\circ} \mathrm{C}$. The
LIT-wash is also incubated at $28^{\circ} \mathrm{C}$ and none of the 50 seeded plasma showed positive result of $T$. cruzi.

According to the literature 13 both LIT and Warren media support growth of $T$. cruzi at least for 3-4 months. Laboratories performing hemoculture can use both media, depending on their facilities.

The association of hemoculture with xenodiagnosis for Chagas was suggested by Chiari \& Brener 4 . We have now evidence that this association should be used specially when blood is collected in field conditions or in areas of Chagas disease where patients show low levels of parasites in the blood.

Repetition of the reported method is recommended, in the same patient two or more times in different occasions, as used in xenodiagnosis in clinical trials (Cançado et $\mathrm{al}^{2}$ ). According to Galvão et ali 8 in 51 untreated patients with $45 \%$ positive in a total of 69 hemocultures with only $12 \%$ of patients being examined more than twice, and in a group of 32 treated patients considered as a therapeutic failure with $31 \%$ positive in 69 cultures, with $49 \%$ being examined more than twice (2-5 times).

The positivity of hemoculture depends upon the group of chronic chagasic patients and the level of low rates of persisting ongoing $T$. cruzi infections.

Hemocultures were important tools for the isolation of strains for biochemical studies (isoenzymes and restricted endonucleases) according to Romanha et ali ${ }^{17}$ and Morel et ali ${ }^{10}$ to characterize $T$. cruzi in human, wild and domestic animals.

Other changes must be tested with the purpose of obtaining higher percentage of positivity to hemoculture technique.

\section{RESUMO}

Objetivando a padronização de uma técnica de hemoculturas que apresente maior taxa de positividade no diagnóstico da fase crônica da doença de Chagas em pacientes com sorologia reativa (TIF, 
Chiari E, Dias JCP, Lana $M$, Chiari CA. Hemocultures for the parasitological diagnosis of human chronic Chagas' disease. Revista da Sociedade Brasileira de Medicina Tropical 22: 19-23, jan-mar, 1989.

$H A, R F C)$ utilizamos o seguinte esquema: o volume de $30 \mathrm{ml}$ de sangue foi colhido heparinizado e o plasma separado por centrifugacao (200 rpm/30'); o sedimento foi lavado com meio LIT ou salina fisiologica tamponada e removido por nova centrifugação (2000 $\left.\mathrm{rpm} / 15^{\prime}\right)$; as células sedimentadas foram distribuidas em 6 tubos tipo "screw" $18 \times 200$ contendo $6,0 \mathrm{ml}$ de meio LIT; as culturas incubadas a $28^{\circ} \mathrm{C}$, foram examinadas após 15, 30, 45 e 60 dias; quando a hemocultura nào foi processada imediatamente após a colheita de sangue, o plasma foi removido e o sedimento, adicionado de meio LIT, conservado a $4^{\circ} \mathrm{C}$; o xenodiagnóstico (Schenone) realizado no mesmo dia da colheita do sangue foi utilizado como técnica de referência.

Entre os vários grupos de pacientes examinados, os melhores resultados forneceram uma positividade de $55,0 \%$ para hemocultura contra $27,5 \%$ de xenodiagnósticos positivos $\left(X^{2}=4,54 ; p=0,05\right)$, com positividade/tubo de $26,6 \%$. A conservação do material a $4^{\circ} \mathrm{C}$ durante 48-72 horas não alterou o percentual de positividade. A positividade dos tubos de hemoculturas mostrou uma redução de 18,0 para $7,2 \%$ quando o plasma não foi removido logo após a colheita do sangue, e mantidas por 24-48 horas a $4{ }^{\circ} \mathrm{C}$ antes da técnica ser processada. É provável que isto se deva à ação lítica de imunoglobulinas presentes no plasma, ou ao potencial macrofágico dos linfócitos.

Recomendamos: (a) a realização de duas ou mais hemoculturas do mesmo paciente com a finalidade de aumentar a positividade, principalmente em condiçōes de campo e em áreas onde os pacientes crônicos apresentam baixos niveis de parasitemia; (b) o emprego desta técnica na triagem de pacientes e no controle parasitológico de cura, em ensaios clínico-terapêuticos; (c) a execução deste método em outros laboratórios com a finalidade de comprovar a viabilidade de seu emprego no diagnóstico de rotina utilizando o meio LIT ou Warren.

Palavras-chaves: Doença de Chagas. Diagnóstico parasitológico. Hemocultura e xenodiagnóstico. Trypanosoma cruzi.

\section{ACKNOWLEDGEMENTS}

We wish to thank Mr. Afonso da Costa Viana and Mr. Orlando Carlos Magno for their technical assistance.

\section{REFERENCES}

1. Albuquerque RDR, Fernandes LAR, Funayama GH, Ferriolli Filho F, Siqueira AF. Hemoculturas seriadas com o meio de Warren em pacientes com reação de Guerreiro-Machado positiva. Revista do Instituto de Medicina Tropical de São Paulo 14: 1-5, 1972.
2. Cançado JR, Brener Z. Terapêutica. In: Trypanosoma cruzi e Doença de Chagas (Brener, Z. \& Andrade, Z.), pp. 362-422. Guanabara Koogan, Rio de Janeiro, 1979.

3. Cerisola JA. El xenodiagnostico. International Symposium on New Approaches in American Trypanosomiasis Research Pan American Health Organization. Belo Horizonte, Brazil, 18-21 March, Scientific Publication n.o $318,1975$.

4. Chiari E, Brener Z. Contribuição ao diagnóstico parasitológico da doença de Chagas na sua fase crônica. Revista do Instituto de Medicina Tropical de São Paulo 8: $134-148,1966$.

5. Chiari E, Lana M, Dias JCP. Crescimento e inibição do Trypanosoma cruzi em hemoculturas de pacientes na fase crònica da doença de Chagas. XIV Congresso da Sociedade Brasileira de Medicina Tropical de João Pessoa, Paraiba, 1978.

6. Chiari E, Dias JCP. Nota sobre uma nova técnica de hemocultura para diagnóstico parasitológico na doença de Chagas na sua fase crônica. Revista da Sociedade Brasileira de Medicina Tropical 9: 133-136, 1975.

7. Freitas JLP. O diagnóstico de laboratório da moléstia de Chagas. Revista Clínica de São Paulo 28: 1-20, 1952.

8. Galvão LMC, Cançado JR, Brener Z, Krettli AU. Hemoculture repeatedly negative in humans with Chagas' disease displaying negative complement-mediated lysis tests after specific treatment suggest cure in infection. Memórias do Instituto Oswaldo Cruz, Rio de Janeiro (suppl.) 81:111, 1981. Proceeding of the XIII Annual Meeting on Basic Research in Chagas' Disease. Caxambu, Brazil, nov. 1986.

9. Minter-Goedbloed E. Hemoculture compared with xenodiagnosis for the detection of $T$. cruzi infection in man and in animals. In: New Approaches in American Trypanosomiasis Research. Proceedings of an International Symposium (Belo Horizonte, 1975). PAHO, Scientific Publication no 318 (Washington), p. 245-252, 1976.

10. Morel CM, Chiari E, Camargo EP, Mattei DM, Romanha AJ, Simpson L. Strains and clones of Trypanosoma cruzi can be characterized by pattern of restriction endonuclease products of kinetoplast DNA minicircles. Proceeding National Academy Sciences USA 77: 68106814, 1980.

11. Mourão OG, Chiari E. Comprovação parasitológica na fase crônica da doença de Chagas por hemoculturas seriadas em meio LIT. Revista da Sociedade Brasileira de Medicina Tropical 5: 215-219, 1975.

12. Mourão OG, Mello OC. Hemocultura para o diagnóstico parasitológico na fase crônica da doença de Chagas. Revista da Sociedade Brasileira de Medicina Tropical 9: 183-188, 1975.

13. Neal RA. Superiority of the culture technique over xenodiagnosis for detection of trypanosomes in Chagas' disease. In: International Congress of Tropical Medicine and Malarial, Athens, Annals, p. 56, 1973.

14. Neal RA, Miles RA. The sensitivity of cultures methods to detect experimental infections of Trypanosoma cruzi and comparison with xenodiagnosis. Revista do Instituto de Medicina Tropical de São Paulo 19: 170-176, 1977a. 
Chiari E, Dias JCP, Lana M, Chiari CA. Hemocultures for the parasitological diagnosis of human chronic Chagas' disease. Revista da Sociedade Brasileira de Medicina Tropical 22: 19-23, jan-mar, 1989.

15. Neal RA, Miles RA. The number of tripomastigotes of Trypanosoma cruzi required to infect Rhodnius prolixus. Revista do Instituto de Medicina Trópical de São Paulo 19: 177-181, 1977.

16. Pifano FC. El diagnóstico parasitológico de la enfermedad de Chagas en fase crónica. Estudio comparativo entre la gota gruesa, el xenodiagnóstico, el hemocultivo y las inoculaciones experimentales en animales sensibles. Archivos Venezolanos de Patologia Tropical 2: 89-120, 1954.

17. Romanha AJ, Silva Pereira AA, Chiari E, Kilgour R. Isoenzymes patterns in Trypanosoma cruzi comparati- ve. Biochemistry and Phisiology 62B: 139-142, 1979.

18. Schenone $H$, Alfaro $E$, Reyes $H$, Taucher $E$. Valor del xenodiagnóstico en la infección chagásica crónica. Boletin Chileno de Parasitologia 23: 149-154, 1968.

19. Schenone H, Alfaro E, Rojas A. Bases y rendimiento del xenodiagnóstico en la infección chagásica humana. Boletín Chileno de Parasitologia 29: 24-26, 1974.

20. Warren LG. Metabolism of Schizotrypanum cruzi Chagas. I. Effect of culture, age and substrate concentration on respiratory rate. Journal of Parasitology 46: 529-39, 1960. 